\title{
Children's rights, international human rights and the promise of Islamic legal theory
}

\author{
DEJO OLOWU \\ Associate Professor in Law, Nelson Mandela University Fort Hare
}

\section{INTRODUCTION}

A perception exists amongst many scholars and writers of Western orientation that Islamic law, and indeed the religion of Islam in its entirety, are antithetical to the protection of international human rights. According to this view Islamic law is a formidable impediment to the universal realisation of the norms of international human rights law. This notion is particularly pronounced in matters pertaining to women, children and other vulnerable groups. ${ }^{1}$ The criticisms levelled against Islamic legal precepts, particularly in the aftermath of post-Cold War terrorist activities and in the face of newage fundamentalism, have further compounded the task of a constructive evaluation of the underpinning ideas of humanism, social justice or dignity in Islamic juristic thought. So engrossed with the gloomy presentation of an Islamic legal stance on human rights was Rhoda Howard that she vehemently asserted that "Islamic conception of justice is not one of human rights." ${ }^{2}$ To Mayer, notwithstanding the endorsement of international human rights treaties by Islamic nations, the promise of such endorsement is prone to erosion through the operation of Islamic law. ${ }^{3}$

This spate of outright denigration of Islamic juristic thought has not been helped by the age-old reluctance of enlightened Muslims trained in Western legal traditions to promote critical inter-cultural discourses on the perceived irreconcilable differences between Islamic and Western notions of human rights. ${ }^{4}$ Fortunately, recently there has been a noticeable growth in the number of Western and non-Western academics and other writers who are

1 See generally Schooley YK "Cultural sovereignty, Islam, and human rights - toward a communitarian revision" (1994) 25 Cumberland Law Review 651-660; Khan I "Islamic human rights: Islamic law and international human rights standards" (1999) Appeal: Review of Current Law and Law Reform 74 .

2 Howard R Human rights and the search for community Boulder CO: Westview Press (1995) 94.

3 Mayer AE Islam and human rights: tradition and practice (2nd ed) Boulder, CO: Westview Press (1995) 64-65.

4 See Safi L "Human rights and Islamic legal reform" <http://www.iiu.edu.my/deed/articles/human3. pdf> (accessed 15 October 2007). See Douglass SL, Dunn RE "Islam: enduring myths and changing realities: interpreting Islam in American schools" (2003) 588 Annals 52-53 (reflecting on the stereotypes and misrepresentations about Islam ingrained in American culture that have in turn tainted meritorious academic engagement with Islamic precepts). 
prepared to discuss the possible linkages of Islamic legal theory and an international human rights ethos. ${ }^{5}$ Explaining this positive trend in scholarly engagement, Simonsen observed:

"The growing interest in the issue of human rights throughout the Islamic world is intimately linked. [...] Politically active groups in all parts of the Islamic world, exhausted by political oppression, saluted the growing international focus on human rights from the middle of the 1970s onwards and tried to take advantage of it. Several Muslim intellectuals argued for a compatibility between Islam on the one hand and the concept of human rights as defined by the UN on the other. A parallel trend has been the publication of a number of books in which Muslim intellectuals argue that human rights have always been an integrated part of Islam along the lines of the Cairo Declaration."

Rather than revisiting the vast amount of scholarly works on the general aspects of Islamic law that hold significant implications for international human rights, the focus of this article is to explore the critical dimensions of Islamic legal theory pertaining to the rights of children, particularly the potential of this theory to reinforce the theoretical understanding of children's rights within the international human rights corpus. Even though there has been scholarly inertia in this field, an effort is made here to highlight Islamic legal notions in complex areas and to accentuate their capacity for deeper reflections on children's rights within the global milieu. While broadly examining the tenets of Islamic juristic thought pertaining to children's rights in general, the article evaluates Islamic legal understanding of the rights of the unborn child in considerable detail, without unnecessarily getting embroiled in the philosophical debates about whether an unborn child is a human being or not. Apart from the more renowned normative framework on children's rights, it is demonstrated, Islamic law also contains extensive provisions that can reinforce global advocacy for the promotion and protection of the status, rights and welfare of children.

\section{OVERVIEW OF THE NORMATIVE FRAMEWORK OF CHILDREN'S RIGHTS}

Since the end of the First World War (1914-1918), the protection of children had emerged as a central concern on the political agenda of the international community. The first conscious effort at setting a legal framework for the protection of children was the Minimum Age (Industry) Convention adopted

5 A'la Mawdudi A "Human rights in Islam" (2nd ed) Leicester UK: The Islamic Foundation (1980) 15-16; Abdullahi An-Na'im Toward an Islamic reformation: civil liberties, human rights, and international law New York: Syracuse University Press, 1990, 52-56; Afshari R "An essay on Islamic cultural relativism in the discourse on human rights" (1994) (16) Human Rights Quarterly 235-276; Heiner Biefeldt "Muslim voices in the human rights debate" (1995) 17(4) Human Rights Quarterly 596; Bakar IA "Human rights in Muslim tradition" (2003) 22(2) Al-Nahdah: Journal of the Regional Islamic Da'wah Council of South East Asia and the Pacific 21-28; Dzuhayatin SR "Mainstreaming human rights in the curriculum of the Faculty of Islamic Law" (2005) 2(1) Muslim World Journal of Human Rights 12.

6 Simonsen JB "Redefining rights: Islamic perspectives and the Cairo Declaration”, in Kirsten Hastrup (ed) Legal cultures and human rights: the challenge of diversity” The Hague: Kluwer Law International (2001) 117 at 125. 
by the International Labour Organisation (ILO) in 1919.7 The defunct League of Nations advanced the agenda a little further with the adoption of the International Convention for the Suppression of Traffic in Women and Children in 1921.8 It was, however, the Geneva Declaration on the Rights of the Child, ${ }^{9}$ adopted in 1924, that for the first time employed the language of "rights" when dealing with the protection of children. Later years were to witness the evolution of more elaborate legal instruments for the protection of the rights of children. Among others, the United Nations (UN) Declaration on the Rights of the Child ${ }^{10}$ and the UN Convention on the Rights of the Child $(\mathrm{CRC})^{11}$ stand out as the most significant global instruments in the field of children's rights. ${ }^{12}$

Apart from these instruments specifically designed for the protection of children's rights, the normative framework of children's rights can be gleaned from various other international instruments. Among these are the Universal Declaration on Human Rights, ${ }^{13}$ the International Covenant on Civil and Political Rights, ${ }^{14}$ and the International Covenant on Economic, Social and Cultural Rights. ${ }^{15}$

Beyond the purview of the UN, a number of other instruments exist within diverse regional arrangements aimed at protecting the rights of children. Included in this category are the African Declaration on the Rights and Welfare of the Child, ${ }^{16}$ the African Children's Charter on the Rights and Welfare of the Child (African Children's Charter),${ }^{17}$ the European Convention on the Legal Status of Children Born out Wedlock, ${ }^{18}$ the European Convention on the Exercise of Children's Rights ${ }^{19}$ and the European Convention on Contracts Concerning Children. ${ }^{20}$ These instruments not only set out the rights to which a child is entitled in specific contexts but also specify the safeguards that States Parties should provide for the welfare of children.

These documents cover a wide area and touch on such matters as the rights of a child to life; to national identity; freedom of expression; freedom of

7 International Labour Organisation, Minimum Age (Industry) Convention as adopted in 1919 as revised in 1937 and 1973 (not ratified by Nigeria).

8 United Nations, International Convention for the Suppression of the Trafficking in Women and Children as adopted in 1921 .

9 Geneva, Declaration on the Rights of the Child, as adopted in 1924.

10 United Nations, Declaration on the Rights of the Child as adopted in 1957.

11 United Nations, Convention on the Rights of the Child as adopted in 1989.

12 For a scholarly discussion of the historical foundations of international legal instruments on children's rights, see Van Bueren G (ed) International documents on children Dordrecht: Martinus Nijhoff Publishers (1993) xv-xix; UN Office of the United Nations High Commissioner for Human Rights (OHCHR), "Fact Sheet No. 10 (Rev. 1) Rights of the Child", <http://www.unhchr.ch/html/menu6/2/ fs10.htm $>$ (accessed 15 October 2007); UNICEF, "Path to the Convention on the Rights of the Child", <http://www.unicef.org/crc/index_30197.html> (accessed 15 October 2007).

13 Universal Declaration on Human Rights as adopted in 1948.

14 International Convent on Civil and Political Rights as adopted in 1966.

15 International Covenant on Economic, Social and Cultural Rights as adopted in 1966.

16 African Declaration on the Rights and Welfare of the Child as adopted in 1979.

17 African Children's Charter on the Rights and Welfare of the Child as adopted in 1990.

18 European Convention on the Legal Status of Children Born out of Wedlock as adopted in 1975.

19 European Convention on the Exercise of Children's Rights as adopted in 1996.

20 European Convention on Contracts on Concerning Children as entered into force in 2005. 
thought, conscience, religion and association; to protection of privacy, family, home, correspondence, honour and reputation; the rights to education, health care, parental care and social security, and the right to protection from physical or mental injury, sexual exploitation and abuse, and from neglect or maltreatment.

As elaborate as all the foregoing instruments might appear, their efficacy within municipal jurisdictions do not match the level of their widespread recognition by States. Even though it is readily acknowledged that children's rights, particularly as encapsulated in the CRC, have gained almost universal acceptance by states, ${ }^{21}$ it is incontrovertible that there exists marked disparity in the attitudes of States towards their effective domestic implementation. ${ }^{22}$ One formidable obstacle to the realisation of children's rights in numerous States has been the question of cultural relativism. ${ }^{23}$ While this article will not re-open the cultural relativism debate on the rights of children, ${ }^{24}$ or human rights in general, ${ }^{25}$ it nevertheless aims at advancing the otherwise unexplored province of Islamic legal theory as it relates to the rights of children in line with the widely accepted principle that rights are interdependent and indivisible. It will do so, not by engaging in detailed comparison of the provisions of international human rights treaties relating to children's rights and their equivalents in Islamic law, but by examining the attitude of Islamic law towards the provision of legal safeguards for the rights and welfare of children and, second, identifying and commenting on the approach that Islamic law and prominent international legal instruments have adopted in this regard. In the course of the discussion, it will highlight some of the basic rights that Islamic law recognises as being due to the child.

Finally, it will also evaluate the significance of extending certain legal rights and safeguards to children in utero, a provision already existing in Islamic law, but over which the existing international human rights instruments relating to children are noticeably silent.

21 As of 14 July 2006 there were 192 States Parties to the CRC: see OHCHR, "Status of ratifications of the principal international human rights treaties", <http://www.ohchr.org/english/bodies/docs/status. pdf $>$ (accessed 15 October 2007). See also Children's Rights Information Network, "Human rightsbased approaches to programming: children", <http://www.crin.org/hrbap/index.asp?action=theme. subtheme\&subtheme $=14>$ (accessed 15 October 2007), observing that the massive number of States Parties to the CRC "provides a powerful endorsement to the significance of children's rights."

22 See Todres J "Emerging limitations on the rights of the child: the UN Convention on the Rights of the Child and its early case law" (1998) 30 Columbia Human Rights Law Review 159.

23 In general, see Mutua M "Human rights: a political and cultural critique" Philadelphia PA: University of Pennsylvania Press (2002) 64-67; Guyora Binder "Cultural relativism and cultural imperialism in human rights law" (1999) 5 Buffalo Human Rights Law Review 211.

24 For a scholarly view on the cultural relativism debate in the children's rights context, see HarrisShort S "International human rights law: imperialist, inept and ineffective? Cultural relativism and the UN Convention on the Rights of the Child” (2003) 25 Human Rights Quarterly 130. See also Brown K "Reconciling customary law and received law in Melanesia: the post-independence experience in Solomon Islands and Vanuatu" Darwin: Charles Darwin University (2005) 158-159.

25 See Ibhawoh B "Cultural tradition and national human rights standards in conflict" in Kirsten Hastrup (ed) Legal cultures and human rights: the challenge of diversity The Hague: Kluwer Law International (2001) 85 at 89-93. 


\section{ISLAMIC LAW AND THE PROTECTION OF CHILDREN}

In discussing the outlook of Islam on the protection of children, it is important to mention that the main source from which one must derive the Islamic legal framework is the Holy Qur'an, the Sunnah, the Ijma' and the Qiyahs, all of which are collectively known as the Sharia, ${ }^{26}$ as the Islamic legal system is based on these texts. ${ }^{27}$ While Muslims accept the Holy Qur'an as the revealed word of Allah, the Sunnah refers to the utterances, traditions or known practices of the Prophet Mohammed (SAW), as recorded by the Prophet's closest family members and companions in volumes known as Hadith. ${ }^{28}$ The Ijma' (consensus) refers to legal rules agreed upon through the consensus of learned Islamic scholars within the Muslim community, where no injunction can be found in either the Holy Qur'an or the Sunnah. ${ }^{29}$ The Qiyahs (analogy) refer to the analogies, inferences and deductions drawn from time to time by Islamic jurists in resolving issues not covered by any of the other sources. ${ }^{30}$

The above-mentioned sources shed some light on why Islam as a religion is often described as "a way of life"; it is because, as Oba argues, "it has laws governing every aspect of life." ${ }^{11}$ Lauren has also argued that Islamic law provides the basis for diverse matters pertaining to "justice, the sanctity of life, personal safety, freedom, mercy, compassion, and respect for all human beings as rooted in the obligations owed by believers to Allah". ${ }^{32}$

The need for identifying legal frameworks to promote and protect the rights and welfare of the child is not only borne out of the conviction that the child, like anyone else, is a human being, but also the recognition, as the core international instruments assert, that the child "by reason of his physical and mental immaturity, needs special safeguard and care." ${ }^{33}$ It will, however, be wrong to assume that the recognition of this special vulnerability of the child and the creation of legal safeguards for the child is an exclusively modern phenomenon. More than a thousand years ago this noble cause of safeguarding the welfare of children was espoused by Islamic law and in pursuit of that commitment certain inalienable rights and legal safeguards were promulgated

26 The Sharia literally means "the way to follow". See Muhammad ibn Idris al- Shafi' "Risala: treatise on the foundations of Islamic jurisprudence" Cambridge: Islamic Texts Society (1993) 5; Khan (fn 1) 76.

27 See Kamali MH "Principles of Islamic Jurisprudence" Cambridge: Islamic Texts Society (1991) 14-43; Dutton Y "Sources of Islamic law: An Overview", <http://www.muhajabah.com/docstorage/dutton. htm> (accessed 15 October 2007).

28 Kamali (fn 27 above) $44-47$.

29 Kamali (fn 27 above) 171. See also Mohamed Abdel-Khalek Omar "Reasoning in Islamic law: Part One" (1997) Arab Law Quarterly 148 at 185.

30 Kamali (fn 27 above) 197-198, 200. See also Hallaq WB "Non-analogical arguments in Sunni juridical Qiyas" in Wael B Hallaq "Law and legal theory in classical and medieval Islam" Brookfield, VT: Variorum (1995) 267. One area where this source has been prominent is issue of smoking among Muslims.

31 Oba AA "Islamic law as customary law: the changing perspective in Nigeria" (2002) 51 International Comparative Law Quarterly 817- 819.

32 Lauren PG "The evolution of international human rights: visions seen" Philadelphia: University of Pennsylvania Press (2003) 8.

33 See UN Declaration of the Rights of the Child (fn 10 above), Preamble para 3 CRC (fn 11 above), Preamble para 9; African Children's Charter, Preamble (fn 17 above) para 6. 
for the benefit of all children. ${ }^{34}$ The Holy Qur'an itself, the primary source of Islamic law, initiated this unprecedented venture by declaring certain basic rights for the protection of children that have acquired universal validity in Islamic juristic thought. In addition to children, there are other persons in society who, because of natural or cultural disabilities, similarly require special protection. This matter was considered of such importance that a whole chapter, Surat al Nisa (the Women) was enacted in the Holy Qur'an to deal with some of the peculiar matters affecting such persons. ${ }^{35}$

Among the rights of children that the Holy Qur'an gives particular attention to are the child's right to life, sustenance, property and freedom of conscience. These are, of course, rights to which every human being is entitled, but because of certain special needs of children and prevailing inimical customary practices the Holy Qur'an considers it necessary to deal with them particularly in relation to children.

In the case of the right to life, for instance, infanticide was a customary practice in many pre-Islamic societies. Some of the causes of infanticide were the fear of penury, or the offering of religious sacrifices or, in the case of daughters, to avoid disgrace. ${ }^{36}$ In unequivocal terms, the Holy Qur'an proclaims: "Whosoever kills a human being (without any reason like) manslaughter, or corruption on earth, it is though he had killed all mankind". ${ }^{37}$ It further adds: "[d]o not kill a soul which Allah has made sacred except through the due process of law". ${ }^{38}$ Thus, according to the Qur'an, any killing without lawful authority constitutes murder in Islamic law and is punishable in this life and in the hereafter. ${ }^{39}$ It is of fundamental value in Islamic juristic thought, therefore, that the life of a child must be preserved. ${ }^{40}$

Furthermore, Islam considers all children - including children in the care of their natural parents - to be vulnerable and thus in need of protection. The Holy Qur'an therefore provides safeguards for children by defining the limits of parental authority. ${ }^{41}$ However, orphaned children are in greater need of protection, and the Holy Qur'an deals separately with the protection of such children. It is assumed that such children include those who might possess some wealth of their own (presumably inherited) and who run the risk of its dissipation in the hands of negligent or avaricious guardians. ${ }^{42}$ In the case of orphans, tradition records Prophet Mohammed (SAW) as declaring: "Do

34 See Ilyas N "Regarding rights of children", <http://www.understanding-islam.com/related/text. asp?type $=$ discussion 8 did $=529>($ accessed 15 October 2007$)$.

35 See Chapter 4 of the Holy Qur'an.

36 See generally Akbar KF "Family planning and Islam: a review" (1974) 17(3) Hamdard Islamicus 4, available at <http://muslim-canada.org/family.htm> (accessed 15 October 2007).

37 Holy Qur'an (fn 35 above) 5: 32. See also 81: 8-9.

38 Holy Qur'an (fn 35 above) 6: 151.

39 According to the Holy Qur'an, "Whoever kills a believer intentionally, his recompense is eternity in hell, and the wrath and curse of God are upon him and a dreadful punishment is prepared for him": Holy Qur'an (fn 35 above) 4: 93.

40 See Holy Qur'an (fn 35 above) 6: 151. For the assertion that the preservation of a child's life is the "third commandment in Islam" see Abdl al Ati H Islam in focus Riyadh: International Islamic Federation of Student Organisations (1986) 133.

41 See, for example, Holy Qur'an (fn 35 above) 17:23; 31:15.

42 See Holy Qur'an (fn 35 above) 4: 5-6, 9-10. 
you like your heart to be tender, and your wishes fulfilled? Be merciful to the orphan. Touch softly his head, and feed him from your food. Your heart will be tender and you will attain your wishes." ${ }^{43}$

As a particular point of reference, the Holy Qur'an's pronouncement "[a]nd in their wealth there is acknowledged right for the needy and the destitute" 4 has been interpreted as an injunction for every Muslim to render assistance to every child, man or woman who lacks the basic necessities of life, whether such people ask for assistance or not. ${ }^{45}$ This is a pointer to the veritable notion of social security in Islamic juristic thought.

In matters of religion and conscience, Prophet Mohammed (SAW) takes particular note of the vulnerability of the child, declaring that every child is born in the true religion but faces the danger of being misguided by its parents. ${ }^{46}$ It is therefore the duty of every parent in Islam to educate and guide a child correctly until the child reaches maturity, when he or she becomes independently responsible for his or her beliefs and actions. It is significant that the often-quoted verse of the Holy Qur'an, "[l]et there be no compulsion in religion", ${ }^{47}$ was revealed to check the attempt of an Ansar Muslim father to force his children to adopt his own religion..$^{48}$

The Holy Qur'an makes the rights of a child to be brought up, cared for, educated and protected the primary responsibility of his or her parents. ${ }^{49}$ The range and details of this right have been explained in the traditions of Prophet Mohammed (SAW), and elaborated on in the legal texts, ${ }^{50}$ so that it covers at least the following matters:

- the child's right to parentage, which includes a legal link with its natural and legitimate father and mother. Parentage in Islamic law is established through marriage, acknowledgement or evidence. Once established, it is binding on both child and parents, and neither has the right to disclaim the other. The relationship of parent and child gives rise to mutual legal

43 Related by Abu Al-Darda, al-Tabarani quoted in Hassan MM Islam: its conception and principles Makkah: Muslim World League (no date) 113.

44 See Holy Qu'ran (fn 35 above) 51:19.

45 Mawdudi, Human rights in Islam (fn 5 above) 31.

46 In the words of the Prophet (SAW): "every child is born into the true religion (fitrah), it is the parents later on who make it into a Jew, or Christian or pagan.": quoted in Abdl al Ati "Family structure in Islam" Indianapolis, IN: American Trust Publications (1982) 189.

47 Holy Qur'an (fn 35 above) 2: 256

48 Ansar Muslims were those Muslims of Madinah who helped the Muhajirin (Muslims of Makka who had migrated to Madinah) to settle in Madinah. The verse in Holy Qur'an 2: 256 is a declaration of Islam's confidence that given the chance to make a choice with the facts available, a mature and sane person will choose Islam as the right guidance. That is why the verse added: "the right guidance (i.e. Islam) is henceforth distinct from error." See also Sâmî al-Mâjid S "Let there be no compulsion in religion" <http://www.islamtoday.com/showme2.cfm?cat_id=298sub_cat_id=6078CFID=241629 258CFTOKEN $=43925266>$ (accessed 15 October 2007).

49 For discussion of this point, see Sheikh Al-Othaimin "The rights of children in Islam", <http://sisters. islamway.com/modules.php?name=News\&file=print\&sid=104> (accessed 15 October 2007).

50 These rights are discussed in many scholarly texts dealing with Islamic family law. See, for example, Abdl al Ati "Family structure in Islam" (fn 46 above) 182-207; Nasir JA "The Islamic law of personal status" London, UK: Graham \& Trotman Publishers (1986) 140-169; Mahmus AB "Protecting women and children under Islamic law" in Awa U Kalu, Osinbajo Y (eds) "Women and children under Nigerian law” Lagos, Nigeria: Federal Ministry of Justice (1989) 51-58. 
rights and obligations relating to such matters as inheritance, guardianship and maintenance. ${ }^{51}$

- the child's right to a proper upbringing that in early infancy includes fostering and custody. The actual nursing of the child is the duty of the mother, ${ }^{52}$ whether or not she remains married to the father. Similarly, the mother has the first claim in the right (or duty) of custody (hadana). ${ }^{53}$ There are elaborate rules in the legal text defining the conditions which a custodian must satisfy, all of which have the object of ensuring that the custodian is capable of providing the care, attention, and moral and physical safety which the child requires, and will not expose the child to any injury or hazard..$^{54}$ If the nurse or custodian is not the biological mother, or if she is the biological mother but she is no longer married to the father, then she will be entitled to be paid a wage in the case of nursing the child, or allowances for the maintenance of the child in the case of custody. In both cases, the responsibility for maintenance is the father's unless the child has its own wealth. ${ }^{55}$

- the child's right to guardianship both of its person (including physical protection and educational training) and property, if the child has any property. This is the duty of the father, or a testamentary guardian, or a person appointed by the court. It should be noted that guardianship is different from custody. The former is primarily the duty of the father and continues until the child is mature. The latter reposes in both parents if they live together, but falls on the mother if she is divorced or widowed. Custody continues from infancy until a boy reaches puberty and a girl gets married. ${ }^{56}$

- finally, the child shares with its parents the mutual rights of inheritance and maintenance. The right to inherit is dependent on who survives the other. The prescribed share is a mandatory right, and between parent and child neither can disinherit the other. The right of maintenance, on the other hand, depends on need. In Islamic law, barring the case of husband and wife, no person who has wealth of his or her own is entitled to maintenance from another. ${ }^{57}$

The above are only some of the rights and entitlements of children in terms of Islamic family law. In their interaction with society, children are entitled to many other rights and safeguards which are elaborated on by Muslim jurists in areas such as criminal law, torts, evidence, procedure, contract and

51 See Nasir JJ "Personal status in Islamic Law" (2nd ed) London, UK: Nelson (1990) 140.

52 See Holy Qur'an (fn 35 above) 2: 233.

53 It must be noted in this regard that opinions differ among scholars as to whether custody (hadana) is the right of the child, the custodian, or God. The only practical implication of this dispute is that if it is held to be solely the right of the custodian, then she is entitled to reject it, otherwise, she is not. See A Mayyara "Sharh cala Tuhfat al hukkam" (2000) 1 Dar al Fikr 269.

54 See generally Mayyara, ibid, at 271-276; Nasir "Personal Status" (fn 51 above) 159-161.

55 See Abdl al Ati Islam in Focus (fn 40 above) 133-134.

56 Another opinion is that it comes to an end for both boys and girls when they attain the age of discretion at which age they can make an independent choice of whom to live with among the parents in case the parents are not living together: ibid.

57 See Al-Othaimin (fn 49 above). 
international relations. It must also be noted that the rights cited above are broadly stated and, although they all have their roots in the Holy Qur'an and are recognised by the consensus of all Muslims, there is not and cannot be expected to be complete agreement on various details. ${ }^{58}$ In all cases, however, it would be safe to posit that the primary aim in the various interpretations is how best the basic purpose will be achieved of equitably protecting the interest of the child. It must be noted that, in pursuing that purpose, no unnecessary demand should be made on the rights of others. This explains why, concerning arrangements for the nursing of a child, the Holy Qur'an says: "A mother should not be made to suffer because of her child, nor should he to whom the child is born (be made to suffer) because of the child." ${ }^{59}$

\section{ISLAMIC APPROACHES TO THE PROTECTION OF CHILDREN'S INTERESTS}

Although the protection of the rights and welfare of children emerged as an early commitment of Islamic law, diverse approaches have been adopted for their realisation. Some of these approaches are set out below.

\subsection{Legal Provisions}

A measure favoured by Islam, which has also been adopted by some of the key international human rights instruments relating to children, is the articulation of children's rights and entitlements in clear, unequivocal, mandatory legal rules and safeguards. According to this approach, it is not enough to merely acknowledge in principle that children are vulnerable and entitled to certain special considerations. The law must make a positive declaration of such rights and provide detailed safeguards. This is the position taken by the Sharia from the very beginning; that is, mere religious and social commitment is not sufficient but must be expressed in detailed legal provisions. ${ }^{60}$ This also appears to be the approach of international human rights instruments in so far as they set out not only the rights to which a child is entitled but also the safeguards which should be enacted by the state in order to ensure that these rights are enforceable.

It is instructive to note that an ancient instrument known as the Madinah Charter, made between Prophet Mohammed (SAW) and the inhabitants of the city of Madinah in $622 \mathrm{CE},{ }^{61}$ which has been referred to as "the first written constitution in Islam and arguably the first constitutional law in

58 See Oba (fn 31 above) 821, asserting, "Islamic law has never been applied as a uniform code of law. In fact, Islamic law does not aim at uniformity. Allowances are given for geographical, cultural, social, and even peculiarities."

59 Holy Qur'an (fn 35 above) 2:233.

60 Malik SH "Shariah: a legal system and a way of life" in Abdul-Rahmon I Doi (ed) "Shariah: the Islamic law" Ibadan Nigeria: Iksan Islamic Publishers (1990) 25-41.

61 Madinah Charter 622 CE reprinted in Maimal Ahsan Khan "Human rights in the Muslim world: fundamentalism, constitutionalism, and international politics" Durham NC: Academic Press (2003) 444. Also available at <http://www.constitution.org/cons/medina/con_medina.htm> (accessed 15 October 2007). 
society", ${ }^{62}$ incorporated human rights notions that could be inferred from the Holy Qur'an. ${ }^{63}$

\subsection{Non-Legal Measures}

Legal rules may be devoid of meaning unless observed and enforced. Yet in the case of provisions of such tremendous social and cultural significance as those relating to the welfare of children, it requires more than the coercive powers of the State and threat of legal sanctions to bring about the required impact. The articulation of children's rights in legal instruments is considered by the Sharia as only one among many measures to be employed. The resort to legal sanctions is viewed as a last and necessary measure. In Islam, law goes hand in hand with religion, education and ethical orientation. ${ }^{64}$ It is, therefore, considered that rules of law will find expression in society through the concerted action of all these influences on personal behaviour.

Thus, the content and curriculum of basic education in Muslim society includes tenets of social rights and duties, including those relating to children, which are part of the daily life of every Muslim. The suras (chapters) of the Holy Qur'an, some basic traditions of Prophet Mohammed (SAW) and some elementary religious texts, to which every Muslim is normally exposed from an early age, provide Muslims with most of what is needed. He or she learns and internalises these obligations that also form part of the mores of Muslim society. In this manner legal provisions, such as those relating to the rights and welfare of children, are raised to the status of religious and social obligations, the mere knowledge of which - not to speak of implementation - attracts reward from Allah.

This sense of religious duty is reinforced by fard kifaya (communal duty) which Islam imposes on Muslims - that is, to raise a group of persons who continuously urge the doing of good (which includes protecting the welfare of children) and restraining oneself and restraining others from evil (which includes prohibiting harm, injury or neglect of children). ${ }^{65}$ This behavioural dimension to the protection of the rights and welfare of a child is encapsulated in the Islamic concept of imaan (innate inclination to trust or believe). In the context of children's protection, it is an expression of a Muslim's faith in Allah and the acknowledgement of His will concerning children. ${ }^{66}$

Interestingly, the non-legal imperative is a discernible undertone in some major international human rights instruments relating to children. In particular, the CRC and the African Children's Charter do not stop at legalistic

62 Yildirim Y "Peace and conflict resolution concepts in the Madinah Charter", <http://www.constitution.org/cons/medina/con_medina.htm> (accessed 15 October 2007).

63 See generally Khan (fn 61 above) 154-155.

64 See Oba (fn 31 above) 822.

65 See Hoy Qu'ran (fn 35 above) 3:104.

66 See generally Elahi M "The rights of the child under Islamic law: the prohibition of the child soldier" (1988) 19 Columbia Human Rights Law Review 259; Bennoune K “As-Salamu 'Alaykum?': humanitarian law in Islamic jurisprudence" (1994) 15 Michigan Journal of International Law 605-643. 
declarations. They require the States Parties to promote the education of children and stipulate in some detail the sort of education to which every child is entitled. ${ }^{67}$ The CRC also specifically provides that its contents should be disseminated and made widely known. ${ }^{68}$ I would contend that the two instruments could also have benefited from provisions requiring that the knowledge and significance of the principles that they embody be made part of the school curriculum in the States Parties. Unfortunately these instruments do not contain such provisions. However, the responsibility of taking measures to promote the purpose of these instruments is that of the States Parties, each of which is obliged to act as appropriate for its own jurisdiction. ${ }^{69}$

\subsection{Moral Responsibility}

In Islamic law the duty of safeguarding the rights and welfare of children is also elevated onto a moral plane as part of the multidimensional approach that Islamic law has adopted in this field. To take good care of children, show them compassion, educate and teach them good manners is, in Islam, among the religious deeds that deserve great commendation. The raising of a disciplined and righteous child, who will grow up to be good and compassionate to its parents, is listed by Prophet Mohammed (SAW) as one of the three good deeds for which a person continues to earn reward long after death. Regarding this tradition Prophet Mohammed (SAW) says: "When a man dies, his acts come to an end except three: recurring charity, or knowledge by which people benefit, or a pious child who prays for him."70

Commenting on the last part of this tradition as narrated in one of the Hadith texts, the Sahih Abdul Hamid, Siddiqi says that the proper upbringing of the children turns them into valuable assets for the society and ensures that they do not become a liability. All their good actions, the prayers they offer for their deceased parents, the moral standards they observe and the fear of God which they show in all activities of their lives become a continuous source of reward for the deceased parents. ${ }^{71}$

According to another tradition, Prophet Mohammed (SAW) viewed commitment to the welfare of children as one of the things that Muslims would take up in a competitive spirit and prophesied that the Muslim community would earn a name among other communities for its kindness to children. ${ }^{72}$

67 See CRC (fn 11 above) art 28; African Children's Charter (fn 17 above) art 11.

68 CRC (fn 11 above) art 42.

69 See CRC (fn 11 above) art 2; African Children's Charter (fn 17 above) art 1(1).

70 Hadith narrated in Sahih Muslim quoted in Al-Othaimin (fn 49 above).

71 See Sahih Muslim Vol. 13, Abu Bakr Siddiqi (translated) (1979).

72 See Abdl al Ati "Family structure in Islam" (fn 46 above) 198. 


\subsection{Importance of the natural family}

Islam places emphasis on the maintenance of the family institution and desires that each child should as far as possible be raised by its natural parents. It also requires that each child should maintain its true identity and keep its legal link with its natural father and mother.

This attitude of Islamic law is revealed in the fact that the tenuous link that is created through adoption is totally rejected. The Holy Qur'an says adopted children are not the real offspring of the adopters. If the natural parents of the adopted children are known, they must be linked with them. ${ }^{73}$ Otherwise, no legal fiction needs be created, and the parentless children will be raised by other members of the Muslim community. By the letters of the Holy Qur'an:

"nor hath He made those whom ye claim [to be your sons] your sons. This is but a saying of your mouths. But Allah sayeth the truth and he showeth the way. Proclaim their real parentage. That will be more equitable in the sight of Allah. And if ye know not their fathers then [they are] your brethren in the faith and your clients." ${ }^{74}$

Adoption is generally not allowed, ostensibly because it disrupts the pattern of family relationships that Islamic law recognises and invests with legal rights and duties. ${ }^{75}$ In some societies, such as pre-Islamic Arabia, adoption occurred hand in hand with certain corollary practices, ${ }^{76}$ such as the right of a family to disclaim a member, or of a person to renounce his biological family, both of which were promoted by the possibility of being adopted into another family. Islamic law prohibits all these practices and demands that every person should maintain his or her natural identity. ${ }^{77}$

The prohibition of adoption, however, does not prevent one person from taking the responsibility of raising the child of another, which is a meritorious deed in Islam, called kafalah, ${ }^{78}$ is widely practiced and could even become a duty. The finder of a foundling, for instance, is duty-bound to take care of it and raise it in the manner he or she would raise his or her own children. Similarly, if natural parents are incapable of raising their child, the Islamic solution is not adoption. It is for Muslim society to assist them, in case they only require material help, or for the child to be placed with other parents who are as closely related to the child's natural family as possible. The new parents will not, in Islamic law, totally displace the natural parents but will perform their function as an act of personal charity or for compensation, according to the demands of each case. ${ }^{79}$

73 Holy Qur'an (fn 35 above) 33: 4-6.

74 Holy Qur'an (fn 35 above) 34: 4.

75 Abdl al Ati "Islam in Focus" (fn 40 above) 192-193.

76 See Abdl al Ati "Family structure in Islam" (fn 46 above) 24.

77 Holy Qur'an (fn 35 above) 33: 4-6. See also van Bueren G "The international law on the rights of the child" Dordrecht: Martinus Nijhoff Publishers (1995) 95.

78 The term kafalah has its roots in the Islamic law of obligations. It permits a person to enter into a contract committing himself/herself to certain undertakings in favour of another person provided that person has a material or moral interest in such undertaking. Even though not on the same legal plane as the Western idea of adoption, it is becoming rampant in transboundary child adoptions even in the Islamic world. See Sfeir GN "Modernisation of the law in Arab states" London: Bethesda Press (1998) 54.

79 See Abdl al Ati "Islam in focus" (fn 40 above) 195-196. 
The importance of raising a child in its natural family environment is recognised by various international human rights treaties relating to children. These instruments also require that alternative care be provided for those children deprived of a natural family environment. ${ }^{80}$ Adoption, as one of such possible alternatives, is allowed by such instruments for those countries where adoption is recognised. ${ }^{81}$ The CRC also specifically mentions "Kafalah under Islamic law" among examples of recognised alternatives. ${ }^{82}$

\subsection{Duties of the Child}

It has already been mentioned above that, in Islamic law, concepts of rights and duties - especially within the family - are reciprocal. Such rights and duties would include the rights of maintenance and inheritance. However, such reciprocity is not confined to material rights. The parents' duty to raise and educate their children, for instance, is reciprocated by the child's duty of ihsan to them, ${ }^{83}$ which has been described as including "kindness, commission, reverence". ${ }^{84}$ Ihsan also includes deference and obedience, but these must be exercised within the limits of the law. For instance, the child is not required to be so submissive to his or her parents that he or she neglects his or her own primary duty, which is obedience to Allah. ${ }^{85}$

To accentuate the culturally cross-cutting idea of the "duties" under discussion, one must observe the importance that the African Children's Charter in particular gives to the duties owed by the child to his or her family and society. It is part of this duty, according to the African Children's Charter, for the child "to work for the cohesion of the family, to respect his parents at all times and maintain them in case of need." ${ }^{86}$ Even though the content of this obligation is yet to be elaborated upon within the African regional human rights system, its significance for social security and family cohesion in the African cultural milieu cannot be overemphasised. It is in that light that the Islamic approaches should be viewed.

\section{RIGHTS OF THE UNBORN CHILD IN ISLAMIC LAW}

There is much debate as to whether unborn children deserve any legal protection. ${ }^{87}$ The arguments and counter-arguments have revolved around what has been described as the key question, namely, "at what point in time does human life come into existence and at what point does society deem such life to acquire legal protection?" 88 Attempts at answering this volatile

80 CRC (fn 11 above); African Children's Charter (fn 17 above).

81 CRC (fn 11 above) art 21; African Children's Charter (fn 17 above) art 24.

82 CRC (fn 11 above) art 20(3). See further discussion in van Bueren (fn 77 above) 102.

83 Ihsan is the Muslim responsibility to obtain perfection, or excellence, in worship, such that Muslims try to worship Allah as if they see Him, and although they cannot see Him, they undoubtedly believe He is constantly watching over them.

84 Abdl al Ati "Family structure in Islam" (fn 46 above) 205.

85 Abdl al Ati "Islam in focus" (fn 40 above) 134.

86 African Children's Charter (fn 17 above) art 31.

87 On this point see Roberts MA "Cloning and harming: children, future persons, and the 'best interest' test” (1999) 13(1) Notre Dame Journal of Law Ethics \& Public Policy 37, 49-57.

88 Fortin J "Legal protection for the unborn child" (1988) 51(1) Modern Law Review 54, 55. 
question have led to a proliferation of lengthy philosophical controversies. Since these have received considerable scholarly investigation, ${ }^{89}$ it is not proposed to explore the details of such debates here. Nevertheless, it cannot be expected that documents of such transnational importance as the CRC and the African Children's Charter can make the desired impact if they avoid controversial questions and confine themselves only to settled issues.

It is significant that, in Islamic law, jurists have avoided becoming bogged down in controversy as to whether or not unborn children deserve legal protection. Not only is the necessity of such protection generally recognised, but the position is further taken that, from the moment of conception, a foetus becomes the recipient of some legal rights. ${ }^{90}$ Muslim jurists, therefore, are not only familiar with the issues that have generated the modern controversy but are able to take the matter beyond these issues. The result is that, in Islamic law, unborn children are not only entitled to legal protection of their health and life, but are held to be the recipients of certain additional rights. For the purpose of entitling unborn children to legal rights, Islamic law invests them with the quality known as dhimma.

However, no international human rights instrument has made any provision for the protection of unborn children, and the definition of "child" is limited to the child in post-natal human form. ${ }^{91}$ Considering the vulnerability of the unborn child as conceived in Islamic law, and given the hazards which modern society increasingly poses to unborn children, I contend that this silence is anomalous. Abortion is an age-old issue on which any human rights treaty dealing with children ought surely to take a position. It is possible that the controversial nature of the subject accounts for the silence in the international human rights instruments - in particular, the CRC and the African Children's Charter. In this regard there seems to be a divergence between the Islamic law jurisprudence and the jurisprudence in International Human Rights Law. In this section, I will explore this tension with specific reference to the attitude of Islamic law to the rights of unborn children.

\subsection{Concept of Dhimma}

Dhimma has been defined in Islamic law as "a quality by which a person becomes fit for what he [or she] is entitled as well as what he [or she] is subject to." 92 In other words, it is a quality inherent in all human beings

89 For some scholarly views in this regard, see Keyserlingk EW "The unborn child's right to prenatal care (Part I)" (1982) 3 Health Law in Canada 10; Robertson JH "Liberalism, identity, and human cloning" (1998) 76 Texas Law Review 1371, 1388-1403; Kaveny MC "Cloning and positive liberty" (1999) 13(1) Notre Dame Journal of Law, Ethics \& Public Policy 15, 23-26.

90 See Syed IB “Abortion" < http://www.irfi.org/articles/articles_101_150/abortion.htm> (accessed 15 October 2007).

91 For a critique of this definitional limitation, see Olowu 'D "Protecting children's rights in Africa: a critique of the African charter on the rights and welfare of the child" (2002) 10(2) International Journal of Children's Rights 127 at 131-132.

92 Abdallah AA "Legal capacity in Islamic law" Zaria Nigeria: Centre for Legal Studies, Monograph Series 1 (1978) 6. 
that enables them to be the repository of rights and obligations. ${ }^{93}$ The legal capacity to bear such rights and obligations is called ahliyyat al wujub. ${ }^{94}$ Dhimma is therefore the basis and a prerequisite for ahliyyat al wujub. It is an exclusively human quality, since only human beings can be the recipients of rights and bearers of responsibilities. To invest unborn children with dhimma is to recognise their independent human status. It would therefore appear that one cannot equate Islamic legal thinking in this area with the common law position in South Africa that a child does not obtain an independent legal status until it is born..$^{95}$

Ahliyyat al wujub is of two types: shakhsiyyah naqisa (i.e. incomplete, partial, or limited) and kamila (i.e. complete). ${ }^{96}$ The unborn child is vested with only limited ahliyyat al wujub which, however becomes complete at the moment the pregnancy is delivered. ${ }^{97}$ In practice, the effect of limiting the ahliyyat of a foetus works more or less to its advantage. Although full ahliyyat al wujub, which is acquired only at birth, makes the child the repository of both rights and obligations, the effect of incomplete ahliyyat al wujub is to divest the unborn child of all obligations.

In Islamic law the unborn child is therefore only the recipient of rights and owes no obligation to anyone at all. ${ }^{98}$ This is indeed an anomaly, for a fundamental principle in Islamic law is that rights always go along with corresponding obligations. ${ }^{99}$ The fact that such a basic rule has been compromised in this instance underlines the significance which Islamic law attaches to the vesting of unborn children with legal rights and protection.

By virtue of its limited ahliyyat al wujub, therefore, the unborn child becomes the recipient of certain rights. These rights may be classified into two ways: The first class provides the unborn child with safeguards for personal protection; the second class enables him to acquire certain material benefits.

93 For a pertinent discussion on this point, see Basir bin Mohamad A "Vicarious liability: a study of the liability of the guardian and his ward in the Islamic law of tort” (2002) 17(1) Arab Law Quarterly 39, 42-45.

94 A leading Islamic scholar has defined this term as "the capacity to receive or inherit rights and obligations." See Saleh N "Definition and formation of contract under Islamic and Arab laws" (1990) 5 (2) Arab Law Quarterly 101-116

95 Fortin (fn 88 above) 54. This position has gained support in recent times. See, for example, Christian Lawyers Association of South Africa v. Minister of Health 19984 SA 1113 (T) where the Transvaal High Court held that the law does not afford legal personality or protection to a foetus. For further scholarly insight into the comparative dimensions of this issue, see Mowbray $\mathrm{K}$ "The rights of the unborn child", <http://www.racgp.org.au/document.asp?id=726> (accessed 15 October 2007).

96 See Zahraa M "Legal personality in Islamic law” (1995) 10(3) Arab Law Quarterly 193, 194.

97 Ibid. See also Hassan Islam: its conception and principles (fn 43 above) 100 (stating that Islamic law recognises a child from "its existence in uterus").

98 See Katme AM “The humane/human rights of the foetus/unborn child in Islam”, <http://beehive. thisiscornwall.co.uk/default.asp?WCI $=$ SiteHome $\& I D=6403 \&$ PageID $=65385>$ (accessed 15 October 2007).

99 Zahraa (fn 96 above). 


\subsubsection{Personal Protection}

For the protection of the unborn child's "life" and "health", Islamic law confers on him or her certain rights under Islamic criminal law and law of torts. If any person commits aggression against a pregnant woman so that the unborn child is aborted, such person is held liable for killing the child in addition to any other liability the person might owe to the mother. ${ }^{100}$ The aggressor is therefore liable to pay a compensation called ghirra, ${ }^{101}$ which most scholars agree is not merely an additional payment to the mother but an independent right of the child to be inherited by its heirs. If the child, whose mother was the victim of such aggression, is delivered alive and then dies from the injury it had sustained in utero, the compensation will be a full diyyah ("blood money"). ${ }^{102}$ The aggressor, if he or she acted deliberately, may also be liable to be punished. ${ }^{103}$

Furthermore, it is to be inferred that in Islamic law any act short of abortion which injures or poses a hazard to the child is equally forbidden, since the principle is that an act that leads to illegality is in itself illegal. The deliberate procuring of an abortion is, of course, also forbidden and punishable, except where it is for the sole purpose of saving the life of the mother ${ }^{104}$ While some Islamic jurists would condone abortion if committed in the first 120 days of gestation, even without any reason of danger to the mother's life, abortion procured any moment after that is generally recognised by Muslims as illegal. ${ }^{105}$

In the world of the 21 st century, however, there is a growing school of thought in the Islamic world which advocates that, among other reasons, the possibility of genetically transmitted diseases, congenital defect or intrauterine diagnosis of a severe foetal abnormality could justify the procurement of an abortion. Added to these is the issue of voluntary abortion of a foetus

100 See Mohamad "Vicarious liability" (fn 93 above).

101 This is an Arabic word also written as ghurrah, which means compensation. This originated from the Holy Prophet's hadith. See Zahraa (fn 96 above) 195.

102 Blood money or diyyah refers to the compensation paid by a killer to the relatives of the victim. However, this Sharia form of penal compensation does not apply to a premeditated killing, and the law of equality or qisas ("tooth for a tooth or an eye for an eye") is strictly applied as a rule. As practised under Sharia or Islamic law, the application of blood money or diyyah connotes the value of saving an individual's life. It is therefore better for relatives of the victim to forgive and accept the diyyah in the form of compensation than allow the hanging or imprisonment of another individual. See Sabiq S "Eigh al Sunna” Vol. 2 Beirut: Dar al-kitab al-Arabi (1980) 565.

103 Katme (fn 98 above). See also Anjem Choudary "Human rights: comparison between the declaration of human rights and divine rights in Islam" <http://downloads.islambase.co.uk/booksOBM/humanrights.pdf> (accessed 15 October 2007).

104 Ghanem I "The response of Islamic jurisprudence to ectopic pregnancies, frozen embryo implantation and euthanasia" (1987) 7(3) Medical Science Law 187 at 189. See also Zahraa (fn 96 above) 195.

105 See Akbar "Family planning and Islam: a review" ( fn 36 above); Al-Qaradawi Y "The lawful and the prohibited in Islam" Lahore Pakistan: Islamic Book Service (1982); Schirrmacher C (Institute for Islamic Studies), "Abortion in Islam” <http://www.islaminstitut.de/english/publications/abortion. htm> (accessed 15 October 2007); Syed (fn 90 above). 
on the ground of rape, which has remained controversial among Islamic legal writers. ${ }^{106}$

One additional right of the unborn child that it only receives indirectly, however, is the responsibility placed on the father to provide additional nourishment to the pregnant wife, on account of the pregnancy.

\subsubsection{Proprietary rights}

The ahliyyat al wujub of an unborn child, though partial, nonetheless enables him or her to acquire proprietary rights through wills and gifts made in his favour and by way of inheritance. I examine the various dimensions of this assertion in some detail. ${ }^{107}$

\section{(a) Wills and gifts}

The making of wills and donations are critical issues in Islamic law, so much that there exist volumes of writings on the subject. ${ }^{108}$ Although under Islamic law, hiba (a gift) and wasiyya (a legacy) have to be accepted by the donee or legatee, an exception is allowed in the case of unborn children. However, the need for acceptance is not dispensed with entirely. Generally speaking, it is required that, for wasiyya and hiba to take effect, the unborn child must be in existence at the time the bequest or gift is declared. This means that, if the mother is a married woman, the child must be born within six months of the making of the will or the donation of the gift since that is the minimum period of gestation. If the mother is a divorcee or a widow and she is observing the iddah (pregnancy period), ${ }^{109}$ the child is entitled if it is born within the maximum period of gestation which the various schools of Islamic law fix at two years (Hanafi School), four years (Maliki, Shafi'i, and Hanbali Schools) and ten months (Shi'a School), to be counted from the termination of the marriage. ${ }^{10}$ These dates are set in order to ensure that the unborn child had

106 For some of the contradictory views on this subject, see Al-Qaradawi "Abortion from an Islamic perspective”, <http://www.islamawareness.net/FamilyPlanning/Abortion/abo_fatwa001.html> (accessed 15 October 2007); Kandil E "Abortion in Islam" <http://www.famsy.com/salam/Abortion41.htm> (accessed 15 October 2007); Haq M "Islam and abortion", <http://www.jamaat.org/qa/abort.html> (accessed 15 October 2007).

107 For general background, see Powers DS “The Islamic inheritance system” (1998) 5 (3) Islamic Law \& Society 285-290; Kimber R “The Qur'anic law of inheritance” (1998) 5(3) Islamic Law \& Society 291-325.

108 A bequest (wasiyya) or will is defined as a transfer to come into operation after the testator's death. The testator is called al-Musi, the legatee or devisee is called al-Musa lahu, and the executor is called al-Wasi. It is a spiritual testament of a man enabling him to make up his shortcomings in the worldly life and securing rewards in the After-Life. Under the Sharia one is entitled to make a will for one-third of one's property and not beyond that, so that the rights of the legal heirs are not adversely affected. See generally Hussain A "The Islamic law of wills", <http://www.islaam.com/ Article. aspx?id=527> (accessed 15 October 2007).

109 In Islamic law, a divorced woman must wait at least three months, and a widow at least four months and ten days, before they can marry again. The main objective appears to be that there should be no doubts as to the identity of the father if the woman gives birth to a child later on. Within this period, it should become obvious whether or not a woman is pregnant. If she turns out to be pregnant, then her waiting period lasts until the birth of the child; otherwise she is free to remarry after the three months are over. See Islahi AA "Tadabbur-i-Quran" 2nd ed, Vol. 1, Lahore: Faran Foundation (1986) 546. See also Zahraa (fn 96 above) 200.

110 Choudary (fn 103 above). 
in fact been conceived at the time of making the gift or bequest. No such requirement, however, applies in the case of bequest under the Maliki school since it is valid, in their view, to make a bequest in favour of those who are yet to be conceived.

Islamic law also allows gifts to be made in favour of "persons" who are yet to be conceived. This is done by allowing the creation of a "life estate" in favour of living persons and then granting the property absolutely to such unborn children. For any gift or bequest in favour of an unborn child to take effect, the child must be delivered alive. In case of a stillbirth, the property reverts to the testator or donor.

\section{(b) Inheritance}

While the property that an unborn child acquires by gift or bequest comes to him or her because of the voluntary and magnanimous act of another person, his or her right to inheritance is a "mandatory" legal right. An unborn child is entitled, like any other person, to a prescribed share in the estate of his or her deceased father or other relations. The child receives a full share as though he or she were present at the time of the death. As in the case of gifts and bequest, the unborn child's right of inheritance is subject to the same two conditions:

- the child must have been conceived at the time of the deceased relation's demise; and

- it must be born, actually or notionally, alive. ${ }^{111}$

\section{CONCLUSION}

Beyond the extensive literature expressing scepticism about the relevance of Islamic legal thinking for human rights in general, and children's rights in particular, this article has tried to highlight critical flag-posts of Islamic juristic thought that hold significant implications for strengthening the international legal regime on the rights of children. It has shown that the rights of children and the safeguards provided for their welfare in Islamic law form a vast subject, covering each facet of a child's life. The fact that the Sharia includes not only law, but also religion and ethics, enables the system it created to offer a multidimensional approach covering the total personality of the child. It treats the legal rights of children in detail but it does not stop at mere legal declarations. It provides enforceable sanctions as well as religious and social measures to promote the welfare of the child.

Under Islamic law, it has been demonstrated, it is not only after the child is born that it begins to acquire legal rights. The law goes further, creating a protective shield around the unborn child from the time of conception and even investing him or her with the capacity to acquire additional benefits. 
While acknowledging that international human rights law represents a giant leap forward in the global effort to extend rights to children in order to facilitate their protection, this article concludes by reiterating two principles of Islamic law which are bound to enrich that effort. The first is the necessity of adopting a multidimensional approach in safeguarding the rights and welfare of children, carrying the struggle for the realisation of this approach from the lofty heights of legalism to the social and moral planes. The second is the extension of that struggle to cover the rights of unborn children. To do so is not merely expedient but necessary for the success of the overall international human rights venture. As Keyserlingk insightfully observed:

"To begin legal protection and comprehensive obligations towards human beings only at birth, is to assume that the most vulnerable period of all human life, the period during which the foundations of childhood and adulthood health are laid, is discontinuous with and of no influence on those later stages." ${ }^{112}$

Far from being an ex cathedra pronouncement on all the dynamics that should inform a global integrative discourse on children's rights, this essay would have served its purpose if it stimulates further intellectual inquiry in this regard.

\section{Bibliography}

Abdallah AA Legal capacity in Islamic law Zaria Nigeria: Centre for Legal Studies, Monograph Series 1 (1978) 6.

Abdl al Ati Family structure in Islam Indianapolis, IN: American Trust Publications (1982) 189.

Abdl al Ati H Islam in focus Riyadh: International Islamic Federation of Student Organisations (1986) 133.

Abu Al-Darda, al-Tabarani quoted in Hassan MM Islam: its conception and principles Makkah: Muslim World League (no date) 113.

Abdullahi An-Na'im Toward an Islamic reformation: civil liberties, human rights, and international law New York: Syracuse University Press (1990) 52-56.

A'la Mawdudi A Human rights in Islam Leicester UK: The Islamic Foundation, 2nd ed (1980)

Brown K Reconciling customary law and received law in Melanesia: the postindependence experience in Solomon Islands and Vanuatu Darwin: Charles Darwin University (2005) 158-159.

Hallaq WB Non-analogical arguments in Sunni juridical Qiyas in Wael B Hallaq Law and legal theory in classical and medieval Islam Brookfield, VT: Variorum (1995) 267.

Howard R Human rights and the search for community Boulder CO: Westview Press (1995) 94

112 Keyserlingk EW “The unborn child's right to parental care - a comparative law perspective” (1984) 5 McGill Legal Studies 79. 
Islahi AA Tadabbur-i-Quran 2nd ed, Vol. 1, Lahore: Faran Foundation (1986) 546.

Keyserlingk EW (1984) The unborn child's right to parental care - a comparative law perspective 5 McGill Legal Studies 79.

Lauren PG (2003)The evolution of international human rights: visions seen Philadelphia: University of Pennsylvania Press 8.

Malik SH (1990) Shariah: a legal system and a way of life in Abdul-Rahmon I Doi (ed) Shariah: the Islamic law Ibadan Nigeria: Iksan Islamic Publishers 25-41.

Mayer AE (1995) "Islam and human rights: tradition and practice" (2nd ed) Boulder, CO: Westview Press 64-65.

Mayyara A Sharh cala Tuhfat al hukkam (2000) 1 Dar al Fikr 269.

Nasir JA “The Islamic law of personal status” London, UK: Graham \& Trotman Publishers (1986) 140-169; Mahmus AB "Protecting women and children under Islamic law" in Awa U Kalu, Osinbajo Y (eds) "Women and children under Nigerian law” Lagos, Nigeria: Federal Ministry of Justice (1989) 51-58.

Nasir JJ (1990) Personal status in Islamic Law (2nd ed) London, UK: Nelson 140.

Sfeir GN "Modernisation of the law in Arab states" London: Bethesda Press (1998) 54.

Van Bueren G (ed) "International documents on children” Dordrecht: Martinus Nijhoff Publishers (1993) xv-xix; UN Office of the United Nations High

Van Bueren G (1995) "The international law on the rights of the child" Dordrecht: Martinus Nijhoff Publishers 95.

Afshari R An essay on Islamic cultural relativism in the discourse on human rights (1994) (16) Human Rights Quarterly 235-276

Bakar IA Human rights in Muslim tradition (2003) 22(2) Al-Nahdah: Journal of the Regional Islamic Da'wah Council of South East Asia and the Pacific 21-28

Bennoune K As-Salamu "Alaykum?: humanitarian law in Islamic jurisprudence" (1994) 15 Michigan Journal of International Law 605-643.

Bin Mohamad A B Vicarious liability: a study of the liability of the guardian and his ward in the Islamic law of tort (2002) 17(1) Arab Law Quarterly 39, 42-45.

Douglass SL, Dunn RE Islam: enduring myths and changing realities: interpreting Islam in American schools (2003) 588 Annals 52-53

Dzuhayatin SR "Mainstreaming human rights in the curriculum of the Faculty of Islamic Law" (2005) 2(1) Muslim World Journal of Human Rights 12.

Elahi M The rights of the child under Islamic law: the prohibition of the child soldier (1988) 19 Columbia Human Rights Law Review 259

Fortin J Legal protection for the unborn child (1988) 51(1) Modern Law Review $54,55$. 
Ghanem I The response of Islamic jurisprudence to ectopic pregnancies, frozen embryo implantation and euthanasia (1987) 7(3) Medical Science Law 187 at 189.5 .

Harris-Short S International human rights law: imperialist, inept and ineffective? Cultural relativism and the UN Convention on the Rights of the Child (2003) 25 Human Rights Quarterly 130.

Heiner Biefeldt, Muslim voices in the human rights debate (1995) 17(4) Human Rights Quarterly 596

Ibhawoh B (2001) Cultural tradition and national human rights standards in conflict in Kirsten Hastrup (ed) Legal cultures and human rights: the challenge of diversity The Hague: Kluwer Law International 85 at 89-93.

Kamali MH "Principles of Islamic Jurisprudence" Cambridge: Islamic Texts Society (1991) 14-43

Kaveny MC Cloning and positive liberty (1999) 13 (1) Notre Dame Journal of Law, Ethics \& Public Policy 15, 23-26.

Keyserlingk E W (1982) The unborn child's right to prenatal care (Part I) 3 Health Law in Canada 10

Khan I (1999) Islamic human rights: Islamic law and international human rights standards Appeal: Review of Current Law and Law Reform 74.

Kimber R (1998) The Qur'anic law of inheritance 5(3) Islamic Law \& Society 291-325.

Mohamed Abdel-Khalek "Omar Reasoning in Islamic law: Part One” (1997) Arab Law Quarterly 148 at 185.

Muhammad ibn Idris al- Shafi'I "Risala: treatise on the foundations of Islamic jurisprudence" Cambridge: Islamic Texts Society (1993) 5

Mutua M "Human rights: a political and cultural critique" Philadelphia PA: University of Pennsylvania Press (2002) 64-67; Guyora Binder "Cultural relativism and cultural imperialism in human rights law" (1999) 5 Buffalo Human Rights Law Review 211.

Oba AA "Islamic law as customary law: the changing perspective in Nigeria" (2002) 51 International Comparative Law Quarterly 817- 819.

Olowu 'D "Protecting children"s rights in Africa: a critique of the African charter on the rights and welfare of the child" (2002) 10(2) International Journal of Children's Rights 127 at 131-132.

Powers DS "The Islamic inheritance system" (1998) 5 (3) Islamic Law \& Society 285-290

Robertson JH “Liberalism, identity, and human cloning” (1998) 76 Texas Law Review 1371, 1388-1403

Roberts MA "Cloning and harming: children, future persons, and the "best interest' test” (1999) 13(1) Notre Dame Journal of Law Ethics \& Public Policy 37, 49-57.

Sabiq S “Eigh al Sunna” Vol. 2 Beirut: Dar al-kitab al-Arabi (1980) 565. 
Saleh N "Definition and formation of contract under Islamic and Arab laws" (1990) 5 (2) Arab Law Quarterly 101-116

Schooley Y K "Cultural sovereignty, Islam, and human rights - toward a communitarian revision" (1994) 25 Cumberland Law Review 651-660

Simonsen JB "Redefining rights: Islamic perspectives and the Cairo Declaration", in Kirsten Hastrup (ed) "Legal cultures and human rights: the challenge of diversity” The Hague: Kluwer Law International (2001) 117 at 125.

Zahraa M "Legal personality in Islamic law" (1995) 10(3) Arab Law Quarterly 193, 194.

Todres J "Emerging limitations on the rights of the child: the UN Convention on the Rights of the Child and its early case law" (1998) 30 Columbia Human Rights Law Review 159.

Akbar KF Family planning and Islam: a review (1974) 17(3) Hamdard Islamicus 4, available at <http://muslim-canada.org/family.htm> (accessed 15 October 2007).

Al-Qaradawi Abortion from an Islamic perspective, <http://www.islamawareness.net /FamilyPlanning/Abortion/abo_fatwa001.html> (accessed 15 October 2007)

Al-Qaradawi Y The lawful and the prohibited in Islam Lahore Pakistan: Islamic Book Service (1982); Schirrmacher C (Institute for Islamic Studies), Abortion in Islam, <http://www.islaminstitut.de/english/publications/abortion. htm> (accessed 15 October 2007); Syed (fn 75 above).

Anjem Choudary Human rights: comparison between the declaration of human rights and divine rights in Islam <http://downloads.islambase.co.uk/booksOBM/humanrights.pdf> (accessed 15 October 2007).

Children's Rights Information Network, Human rights-based approaches to programming: children, <http:/www.crin.org/hrbap/index.asp?action=theme. subtheme\&subtheme $=14>$ (accessed 15 October 2007)

Commissioner for Human Rights (OHCHR), "Fact Sheet No. 10 (Rev. 1) Rights of the Child", <http://www.unhchr.ch/html/menu6/2/fs 10.htm> (accessed 15 October 2007)

Dutton Y "Sources of Islamic law: An Overview", <http://www.muhajabah. com/docstorage/dutton.htm> (accessed 15 October 2007).

Ilyas N "Regarding rights of children", http://www.understanding-islam.com/ related/text.asp?type=discussion\&did=529 (accessed 15 October 2007).

Hussain A The Islamic law of wills, <http://www.islaam.com/Article. aspx?id=527> (accessed 15 October 2007).

Ilyas N "Regarding rights of children", http://www.understanding-islam.com/ related/text.asp?type=discussion\&did=529 (accessed 15 October 2007).

Kandil E "Abortion in Islam" <http://www.famsy.com/salam/Abortion41. htm> (accessed 15 October 2007); Haq M "Islam and abortion", <http:// www.jamaat.org/qa/abort.html> (accessed 15 October 2007). 
Katme AM "The humane/human rights of the foetus/unborn child in Islam", $<$ http://beehive.thisiscornwall.co.uk/default.asp?WCI=SiteHome $8 I D=640$ 38PageID=65385 $>$ (accessed 15 October 2007).

Madinah Charter $622 \mathrm{CE}$ reprinted in Maimal Ahsan Khan "Human rights in the Muslim world: fundamentalism, constitutionalism, and international politics" Durham NC: Academic Press (2003) 444. Also available at $<$ http:// www.constitution.org/cons/medina/con_medina.htm> (accessed 15 October 2007).

Mowbray Karen "The rights of the unborn child" < http://www.racgp.org.au/ document.asp?id=726> (accessed 15 October 2007).

Office of the High Commissioner on Human Rights, "Status of ratifications of the principal international human rights treaties", <http://www.ohchr.org/ english/bodies/docs/status.pdf> (accessed 15 October 2007)

Safi L "Human rights and Islamic legal reform" < http://www.iiu.edu.my/deed/ articles/human3.pdf> (accessed 15 October 2007).

Sâmî al-Mâjid S "Let there be no compulsion in religion" <http://www.islamtoday.com/showme2.cfm?cat_id=298sub_cat_id=6078CFID $=241629258$ CFTOKEN $=43925266>$ (accessed 15 October 2007).

Sheikh: Al-Othaimin "The rights of children in Islam”, <http://sisters.islamway. com/modules.php?name=News\&file=print\&sid=104> (accessed 15 October 2007).

Syed IB “Abortion” <http://www.irfi.org/articles/articles_101_150/abortion. htm> (accessed 15 October 2007).

Yildirim Y"Peace and conflict resolution concepts in the Madinah Charter", $<$ http://www.constitution.org/cons/medina/con_medina.htm> (accessed 15 October 2007).

UNICEF, "Path to the Convention on the Rights of the Child", <http://www. unicef.org/crc/index_30197.html> (accessed 15 October 2007).

Christian Lawyers Association of South Africa v Minister of Health 1998 (4) SA $1113(\mathrm{~T})$

African Children's Charter on the Rights and Welfare of the Child as adopted in 1990.

African Declaration on the Rights and Welfare of the Child as adopted in 1979.

European Convention on Contracts on Concerning Children as entered into force 2005.

European Convention on the Exercise of Children's Rights as adopted in 1996

European Convention on the Legal Status of Children Born out of Wedlock as adopted in 1975.

Geneva, Declaration on the Rights of the Child, as adopted in 1924.

International Convent on Civil and Political Rights as adopted in 1966. 
International Covenant on Economic, Social and Cultural Rights as adopted in 1966.

International Labour Organisation, Minimum Age (Industry) Convention as adopted in 1919 as revised in 1937 and 1973 (not ratified by Nigeria).

United Nations, Convention on the Rights of the Child as adopted in 1989.

United Nations, Declaration on the Rights of the Child as adopted in 1957.

Universal Declaration on Human Rights as adopted in 1948.

United Nations, International Convention for the Suppression of the Trafficking in Women and Children as adopted in 1921. 